\title{
Achieving Agility and Dynamic Capabilities on Sustainable Performance: Evidence from the Upstream Oil and Gas Sector
}

Submitted 05/10/20, 1st revision 01/12/20, 2nd revision 09/12/20, accepted 15/12/20

\author{
Muhammad Zulkifli ${ }^{1}$, Firmanzah ${ }^{2}$, Tengku Ezni Balqiah ${ }^{3}$, \\ Mohammad Hamsal ${ }^{4}$
}

\begin{abstract}
:
Purpose: This paper aims to seize the understanding of the effect of TMT commitment (TMC), leadership agility development (LAD), field agile leader (FAL), and operational capabilities $(O C)$ on the field unit performance (FUP) in Indonesia oil and gas sector.

Design/methodology/approach: Research instruments were developed and distributed throughout field operation units in the Indonesian oil and gas sector, resulting in 175 data from field operation leaders across Indonesia's operating oil and gas companies. Structural equation modeling (SEM) LISREL were used to examine the developed hypotheses.

Findings: This research finds that TMT commitment and leadership agility development on field agile leaders, directly and indirectly, play a significant role in the Indonesian oil and gas sector. Leadership agility development has a strong influence on the field of an agile leader. Furthermore, field agile leaders influence operational capabilities, which then affects unit performance significantly.

Practical Implications: The findings have several implications for professionals in the oil and gas sector. The finding of this research also describes the pivotal role of leadership agility development to make the leader more resilient and agile.

Originality/value: The proposed model will describe the input-process-output phases in creating value. This research also contributes to how leadership agility can be promoted and organizational agility and development.
\end{abstract}

Keywords: TMT commitment, leadership agility development, field agile leader, operational capabilities, unit performance.

JEL codes: 014,021 .

Paper Type: Research article.

ISSN: 2241-4754, H index 10, Q3.

\footnotetext{
${ }^{1}$ Faculty of Economics and Business, University of Indonesia, Muhammad.Zulkifli@medcoenergi.com

${ }^{2}$ Faculty of Economics and Business, University of Indonesia, firmanzah.d@ui.ac.id;

${ }^{3}$ Faculty of Economics and Business, University of Indonesia, tengku.ezni@ui.ac.id;

${ }^{4}$ Department of Management, BINUS Business School, Bina Nusantara University,

Indonesia, mhamsal@binus.edu;
} 


\section{Introduction}

The oil and gas sector is still the primary energy source globally and has a significant impact on the global economy as one of the essential indicators (Welfens, Perret, and Erdem, 2011; Khatib, 2012). As the primary source of energy globally, oil and gas are becoming a crucial role in the 21 st century. The oil and gas sector also suffers in the wake of Covid-19 (Figure 1). Oil prices have decreased since January 2020, when many countries on lockdown significantly less of all activities, and make the demand for oil and gas has fallen spectacularly.

Figure 1. Correlation between Oil price Fluctuation and COVID-19

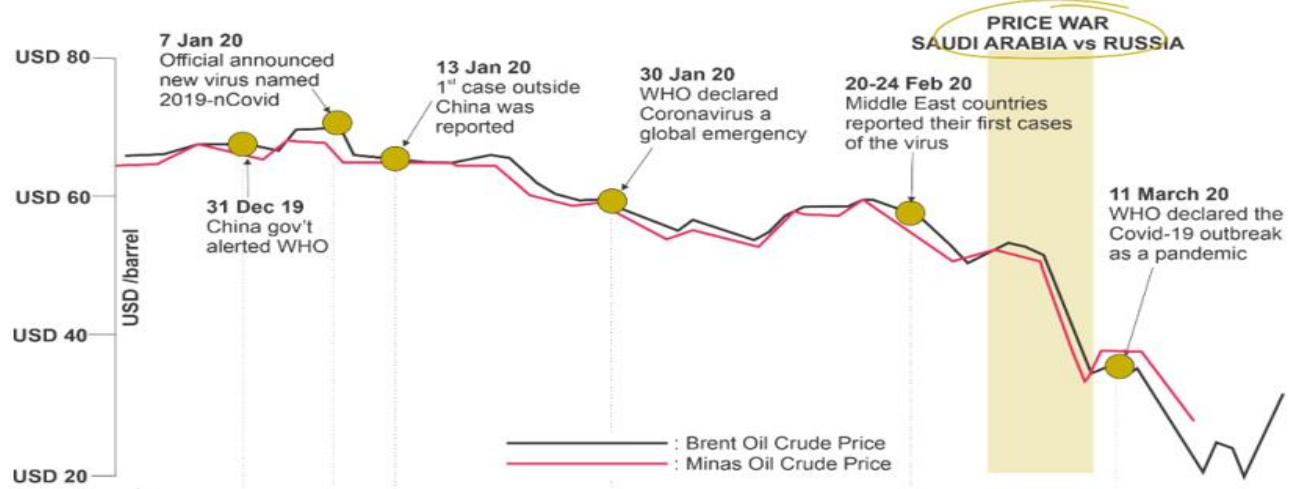

Source: Processed from Trading Economics, 2020.

The oil and gas business has many challenges on each element of the oil business chain, including this pandemic; it requires a proper acceptance of this industry (Schweitzer, 2010). Price instability is not only a significant challenge for the oil and gas industry (Regnier, 2007). They force the managers to increase the value creation as an alternative of output due to low returns (Ramos, Taamouti, Veiga, and Wang, 2017; Pociovalisteanu et al., 2010).

A survey conducted by Fraser Institute in 2017 found several indicators that prevent the investor from coming to Indonesia, including the complexity and uncertainty in field operations. Several studies (Zhao and Hsu, 2007; Phene and Almeida, 2008) argue that external learning sources are more effective in facing uncertain conditions. This forces the managers to increase the value creation as an alternative of output due to low returns (Ramos, Taamouti, Veiga, and Wang, 2017).

\section{Literature Review}

The oil and gas business characteristic has many resources, including the capital, high technology, and complex activities and uncertainty showed by increased safe production and reserves (Bayerl and Lauche, 2010). The uncertainty, ambiguity, and turbulence characterize in oil and gas business environments allow the corporation to respond rapidly and efficiently to market disruptions (Shafer, Dyer, Kilty, Amos, 
and Ericksen, 2001; Dyer and Shafer, 2003). This research aims to advance the inquiry of an agile leader toward orchestrating, which connects various resources by integrating multiple capabilities, as well, as to how the role of a field agile leader can influence field activities (Dutton et al., 2001; O'Brien et al., 2012). A leader at the oilfield needs to understand strategic planning in the integrated approach in managing turbulence, uncertainty, and dynamics (Bolisani and Bratianu, 2017).

Thao (2012) conducted a study on the agile organization focusing on developing and exploring a causal model when an organization operates in a relatively unstable environment. Stekelenburg (2012) found that an organization could become agile by improving individual competence in organization. Studies have proven that leadership capability development integrates various capabilities and how the role of a field agile leader can influence field activities (Dutton et al., 2001; O'Brien's, 2012).

The commitment of top management encourages executing a strategic plan (AragonCorrea et al., 2004; Ng and Wyrick, 2011) in improving leadership performance in the field (Prabhu and Robson, 2000). To improve leadership agility, developing prospective company leaders by transforming and exploiting new knowledge for the company's strategic goals going forward (Zahra and George, 2002), including in increasing the capacity of agility as initial capital for prospective leaders.

\section{Hypothesis 1 (H1): TMT Commitment has a positive effect on Leadership Agility Development.}

In the managerial capability dynamic concept, managerial human capital refers to improving skills, competence, and knowledge, which must be possessed by every leader (Adner and Helfat, 2003). Sirmon and Hitt (2009) highlighted how leaders are identified, recruited, organized, and even maintained to achieve harmony as a company strategy in facing environmental changes. Chang et al. (2011) discussed several factors that can improve innovation through human capital management practices, selection, and training processes.

According to Lengnick-Hall et al. (2011), there are several dimensions of capacity for resilient agility, including cognitive, behavioral, and contextual. The program for developing the leaders with cognitive abilities possessed by a leader can contribute to agility and resilience, including collaborating with various functions with different skills that allow for core values to develop amid uncertainty due to crisis. The contextual dimension programs can have leaders who can develop personal connections and supply lines of resources that can act quickly. Broadly information and knowledge sharing include (a) partners with employees and teams and networks, (b) user-friendly, accessible, and integrated information, (c) empowerment, (d) results-based assessment, and (e) open communication (Lengnick-Hall et al., 2011).

Hypothesis 2 (H2): Leadership Agility Development has a positive effect on Field Agile Leader. 
Top management commitment is the commitment from management through actions (Staw, 1976) with a tendency towards support, business, and real actions (Shah, 1996; Chowdhury et al., 2007). Top management support at corporate is formed towards critical resources for the organization's sustainability in the field. The top management commitment towards the vision, planning, and strategy implementation (Chowdhury et al., 2007) correlated positively with the clarity of the company vision and involvement in making strategic decisions (Cowling and Sugden, 1998) in order to the field agile leader formulate strategic execution and implementation at field including project management, drilling, and operations activities.

The commitment of top corporate management includes supporting the leader on activities, considerations towards suitable choices, idea stimulations, and improvements in field leaders' motivations (Hopkins and Hopkins, 1997), including in how field leaders communicate and interact with their team members in the field (Powell, 1992). Besides, a strategic commitment results in greater field agility, causing the leaders to act more expediently when faced with opportunities to prioritize their tasks according to the strategic plan (Breu et al., 2002).

Bayerl and Lauche (2010) wrote that coordination is needed because it is spread out naturally and not because of business decisions. In implementing this coordination, managers need top management's support and commitment to be successful (Vecchio and Gobdel, 1984). Top management's commitment will help field leaders coordinate in maintaining long-term efficiency and effectiveness (Van Der Vegt $e t$ al., 2015). By committing management, especially top management, operational projects, and drilling can be carried out effectively to fulfill the stakeholders' targets, including increasing company profit (Miller and Pazgal, 2002).

It is not easy to do this because the commitment must be real, consistent, and seen at every level (Sakthivel, 2007), whether in the form of effort or resources (Shah,1996; Chowdhury et al., 2007). The commitment of top management at a corporation is a vital factor in influencing field leaders to implement a strategic project so that its implementation runs effectively in the field (Floyd and Wooldridge, 1992; Shah, 1996).

Hypothesis 3 (H3): TMT Commitment has a positive effect on field agile leader.

The top management commitment at corporate is in the form of management support in conducting a job (Shah, 1996) by allocating all its resources (Chowdury et al., 2007). Without a commitment from top management, the planning process, coordination, and project implementation could fail (Shah, 1996). Important tasks from the top management team are to allocate resources, appoint leaders, develop organizational capabilities, and observe performance.

Agility is a concept in the context that is predominantly about flexible operations systems (Christopher and Towill, 2002). Agility in an organization refers to an 
organization's capability to capture the prospects, threats, and returns by assembling the needed organizational resources with rapidity (Overby et al., 2006). Research conducted by Joiner (2009) revealed that agile leaders' behaviors are attached to a distinct set of mental and emotional capacities that can be learned and developed.

According to Teece, Peteraf, and Leih (2016), the risk, complexity, and uncertainty are recognized; therefore, agility is needed to achieve a more favorable outcome concerning becoming flexibility and efficiency. Therefore, based on the above arguments, we hypothesize that:

Hypothesis 4a (H4a): TMT Commitment has a positive effect on operational capability.

Hypothesis $4 b$ (H4b): Leadership agility development has a positive effect on operational capability.

Hypothesis 4c (H4c): Field agile leader has a positive effect on operational capability.

Operational capability integrates a series of complex activities carried out by a company to improve the performance to be more efficient (Dutta et al, 1999; Hayes et al., 1988). Cepeda and Vera (2007) regarded operational capabilities as part of dynamic capabilities. An operation can be made superior by improving its efficiency in the operational process to reach a competitive advantage (Day, 1994).

The impact of dynamic capabilities on financial performance is realized by improving a firm's operational routines (Zott, 2003). These routines manifest as competitive capabilities such as quality, reliability, and process innovation. Even though the dominant logic supports the mediated impact of dynamic capabilities on financial performance by improving competitive operational capabilities, some evidence is available to affect the competitiveness of cost-effectiveness directly. Based on the above elaboration, it is reasonable to hypothesize:

Hypothesis 5 (H5): Operational capability has a positive effect on field unit performance.

\section{Research Methodology}

This study's data is that of middle-level managers who serve as field leaders. The collected sample data are then analyzed using two methods, i.e., descriptive analysis and analysis measurement using structural equation modeling (SEM). This study adopted a systematic probability technique with the respondents from the oil and gas sector fields. The respondents were selected based on several specific related profiles, such as operations manager, project manager, and drilling manager or superintendent. The sample was selected from a population with particular standards. Data from 175 respondents were gathered through an online questionnaire by accepting a maximum likelihood sampling with a range of 50-100 respondents (Hair et al., 2010) to achieve SEM's numerical requirements (Table 1). 
Table 1. Research variables, dimensions, and indicator codes

\begin{tabular}{|c|c|c|c|}
\hline Variables & Dimensions & Number of Indicators & References \\
\hline \multirow{3}{*}{$\begin{array}{l}\text { Top } \\
\text { Manageme } \\
\text { nt Team } \\
\text { Commitme } \\
\text { nt }\end{array}$} & $\begin{array}{l}\text { Internal } \\
\text { Commitment }\end{array}$ & 8 (TMCIN1-TMCIN8) & \multirow{3}{*}{$\begin{array}{l}\text { Fattouh \& Darbouche, 2010; } \\
\text { Sheikhzadeh et al., 2012; } \\
\text { Acha \& Finch, 2005; Haque et } \\
\text { al., 2004; Chowdhury et al., } \\
\text { 2007; Shah, } 1996\end{array}$} \\
\hline & $\begin{array}{l}\text { Working } \\
\text { Environment }\end{array}$ & $\begin{array}{l}6 \text { (TMCWE1- } \\
\text { TMCWE6) }\end{array}$ & \\
\hline & $\begin{array}{l}\text { External } \\
\text { Commitment }\end{array}$ & 7 (TMCEX1-TMCEX7) & \\
\hline \multirow{3}{*}{$\begin{array}{l}\text { Leadership } \\
\text { Agility } \\
\text { Developme } \\
\text { nt }\end{array}$} & $\begin{array}{l}\text { Cognitive } \\
\text { Development }\end{array}$ & $\begin{array}{l}7 \text { (LADCG1- } \\
\text { LADCG7) }\end{array}$ & \multirow[t]{3}{*}{$\begin{array}{l}\text { Lengnick-Hall et al., 2011; } \\
\text { Chatman et al., } 2005 .\end{array}$} \\
\hline & $\begin{array}{l}\text { Behavior } \\
\text { Development }\end{array}$ & $\begin{array}{l}7 \text { (LADBV1- } \\
\text { LADBV7) }\end{array}$ & \\
\hline & $\begin{array}{l}\text { Contextual } \\
\text { Development }\end{array}$ & 7 (LADCT1- LADCT7) & \\
\hline \multirow{3}{*}{$\begin{array}{l}\text { Field Agile } \\
\text { Leader }\end{array}$} & Sensitivity & 6 (FALSE1-FALSE6) & \multirow{3}{*}{$\begin{array}{l}\text { Sharifi \& Zhang, 2001; } \\
\text { Sambamurthy et al., 2003; } \\
\text { Teece et al., 1997; Zott, } 2003\end{array}$} \\
\hline & Flexibility & 6 (FALFL1 - FALFL6) & \\
\hline & Speed & 6 (FALSP1-FALSP6) & \\
\hline \multirow[t]{3}{*}{$\begin{array}{l}\text { Internal } \\
\text { Operational } \\
\text { Capability }\end{array}$} & $\begin{array}{l}\text { Capability to } \\
\text { Govern the } \\
\text { Business } \\
\text { Process }\end{array}$ & 5 (IOCBP1-IOCBP5) & \multirow[t]{3}{*}{$\begin{array}{l}\text { Jugdev et al., 2007; Keegan \& } \\
\text { Turner, 2002; Soderlund, } \\
\text { 2004; Zott, } 2003\end{array}$} \\
\hline & $\begin{array}{l}\text { Team } \\
\text { Capability }\end{array}$ & 7 (IOCTC1-IOCTC7) & \\
\hline & $\begin{array}{l}\text { Capability to } \\
\text { Plan, Control } \\
\text { \& Evaluation }\end{array}$ & 7 (IOCPC1-IOCTC7) & \\
\hline \multirow{2}{*}{$\begin{array}{l}\text { Field Unit } \\
\text { Performanc } \\
\text { e }\end{array}$} & $\begin{array}{l}\text { Accomplishme } \\
\text { nt }\end{array}$ & 7 (FUPAC1-FUPAC7) & \multirow{2}{*}{$\begin{array}{l}\text { Asrilhant et al., 2006; } \\
\text { Stonham, 2000; O'Dea \& Flin, } \\
\text { 2001; Collins, 1971; Eweje, } \\
2006\end{array}$} \\
\hline & $\begin{array}{l}\text { Cost- } \\
\text { Effectiveness } \\
\text { Social Impact }\end{array}$ & $\begin{array}{l}5 \text { (FUPCE1-FUPCE5) } \\
6 \text { (FUPCE1-FUPCE6) }\end{array}$ & \\
\hline
\end{tabular}

Source: Own study.

\subsection{Measures}

Figure 1 shows the research model, which consists of 5 research variables: TMT commitment (TMC), leadership agility development (LAD), field agile leader (FAL), internal unit capabilities (IOC), and field unit performance (FUP). These research variables were expanded further by adding measurement dimensions as well as indicators. Definitions of the research variables and their dimensions are listed in Table 1.

Data were analyzed using SEM with a sample size of 175 . One of the main reasons for using SEM is that it provides an appropriate and most efficient approximation techniques for a series of separate multi-regression equations estimated concurrently (Hair et al., 2013), and the variables in the model of research as LVs cannot be calculated directly but through indicators or observed variables. It is known as a model of measurement 1 in SEM. The other reason is that relationships among LVs 
are quite involved in the form of simultaneous equations. It is known as a structural model in SEM (Hair et al., 2013).

Figure 1. Research model: The second-order approach

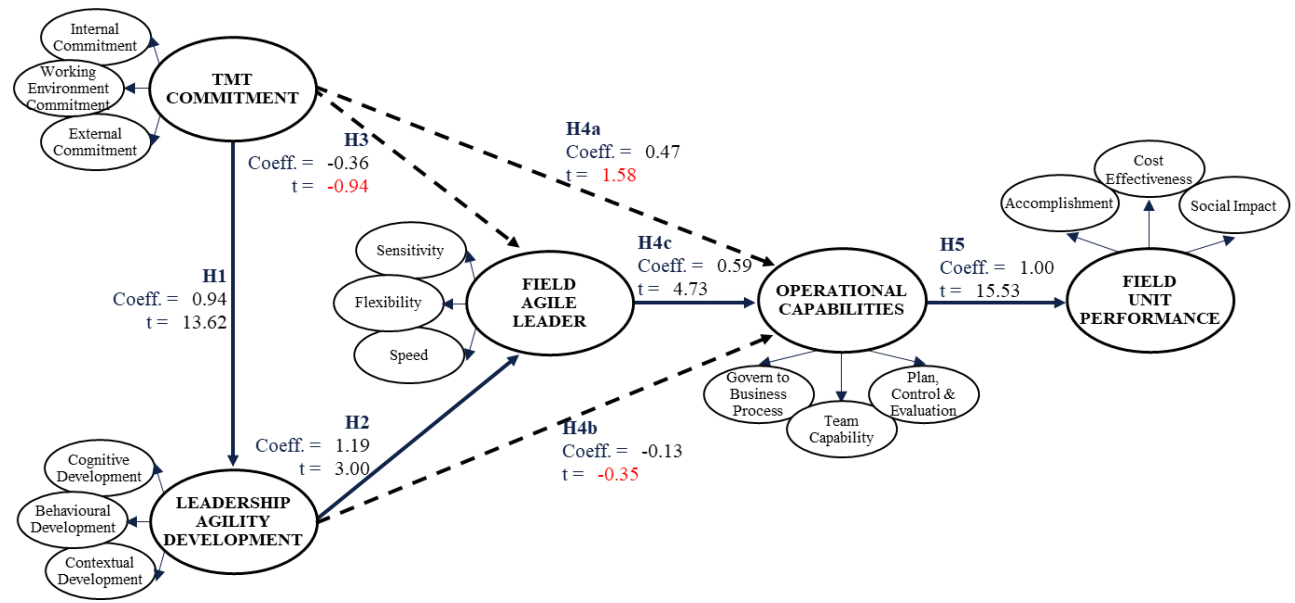

Source: Own study.

\section{Results}

An assessment of the validity of indicators on their dimensions (1st Order CFA) is executed by analyzing these indicators' standardized factor loading (SFL). If the SFL of an indicator is $\geq 0.50$, the indicator is regarded as valid. If the SFL is $<0.50$, then the indicator is not valid and excluded or dropped from the measurement model. The results show that the indicators in Table 1 had an SFL of higher than 0.50; thus, they all were valid indicators/measurements of their stated dimensions. A similar procedure was applied to evaluate the validity of dimensions for their related research variables.

The results show that all dimensions were valid measurements of their associated variables. An evaluation of the reliability of the measurement model of the dimensions (1st Order CFA) and research variables (2nd Order CFA) was executed by testing the variance extracted (VE) and construct reliability (CR). If a measurement model had $\mathrm{VE} \geq 0.50$ and $\mathrm{CR} \geq 0.70$, then the measurement model had good reliability (Wijanto, 2015).

All measurement models of the dimensions had $\mathrm{CR} \geq 0.70$, whereas some had VE slightly $<0.50$. However, in general, these dimensions had good reliability. Meanwhile, all five measurement models of the research variables had VE $\geq 0.50$ and $\mathrm{CR} \geq 0.70$. It means that all research variables had good reliability. Thus, it can be concluded that the measurement models of the research variables have good validity and reliability. After a valid and reliable measurement model was obtained, the next step was to calculate the latent variable score (LVS) of the dimensions and four research variables (Jöreskog and Sörbom, 2006). Bentler and Chou (1987) 
suggested a rule of thumb related to the minimum sample size required by SEM, five units of analysis for each model indicator (Table 2).

Table 2. Summary of estimation results and overall model fit

\begin{tabular}{llll}
\hline Path & Coefficient & t-value* & Conclusion \\
\hline TMC $\geq$ LAD & 0.94 & 13.62 & Significant Positive \\
LAD $\geq$ FAL & 1.19 & 3.00 & Significant Positive \\
TMC $\geq$ FAL & -0.36 & -0.94 & Not Significant \\
TMC $\geq$ IOC & 0.47 & 1.58 & Not Significant \\
LAD $\geq$ IOC & -0.13 & -0.35 & Not Significant \\
FAL $\geq$ IOC & 0.59 & 4.73 & Significant Positive \\
IOC $\geq$ FUP & 1.00 & 15.53 & Significant Positive
\end{tabular}

GOFI: RMSEA $\left(\leq 0.08^{* *}\right)=0.074$; CFI $(\geq 0.90 * *)=0.99$; IFI $(\geq 0.90 * *)=0.99$; NFI $(\geq 0.90 * *)=0.98$

Source: Own study.

Table 3 describes the research hypotheses, where $\mathrm{H}_{1}, \mathrm{H}_{2}, \mathrm{H}_{4 c}$, and $\mathrm{H}_{5}$ have significant positive results. Therefore it can be concluded that they supported the hypotheses.

Table 3. Test Results of Research Hypotheses

\begin{tabular}{|c|c|c|}
\hline Hypotheses of Research & Results & Conclusion \\
\hline $\begin{array}{l}\mathrm{H}_{1} \text { : TMT Commitment has a positive } \\
\text { effect on Leadership Agility Development }\end{array}$ & Significant Positive & H1 Supported \\
\hline $\begin{array}{l}\mathrm{H}_{2} \text { : Leadership Agility Development has a } \\
\text { positive effect on Field Agile Leader }\end{array}$ & Significant Positive & H2 Supported \\
\hline $\begin{array}{l}\mathrm{H}_{3} \text { : TMT Commitment has a positive } \\
\text { effect on Field Agile Leader }\end{array}$ & Not Significant & H3 Not Supported \\
\hline $\begin{array}{l}\mathrm{H}_{4 \mathrm{a}} \text { : TMT Commitment has a positive } \\
\text { effect on Operational Capability }\end{array}$ & Not Significant & H4a Not Supported \\
\hline $\begin{array}{l}\mathrm{H}_{4 b} \text { : Leadership Agility Development has } \\
\text { a positive effect on Operational Capability }\end{array}$ & Not Significant & H4b Not Supported \\
\hline $\begin{array}{l}\mathrm{H}_{4 \mathrm{c}} \text { : Field Agile Leader has a positive } \\
\text { effect on Operational Capability }\end{array}$ & Significant Positive & H4c Supported \\
\hline $\begin{array}{l}\mathrm{H}_{5} \text { : Operational Capability has a positive } \\
\text { effect on Field Unit Performance }\end{array}$ & Significant Positive & H5 Supported \\
\hline
\end{tabular}

Source: Own study.

The results are presented in Table 3. The data support only four out of seven hypotheses. As shown in Table 2, the coefficients of TMC are 0.94 for LAD and 0.36 for FAL. Meanwhile, the remaining significant coefficients are 1.19 for LAD to FAL, 0.47 for FAL to IOC, and 1.00 for IOC to FUP. The simplified research model has significantly affected when t-value more than 1.96 (Figure 4), except for TMC to FAL (-0.94), TMC to IOC (1.58), and LAD to IOC (-0.35), which signifies the insignificant relationship. 


\section{Discussion}

This research finds that TMT commitment and leadership agility development on field agile leaders, directly and indirectly, play a significant role in the Indonesian oil and gas sector. Simultaneously, the top management team commitment also influences leadership agility development as a mediating role to the agile leader. This has aligned with Lengnick-Hall et al. (2011), who discovers that agile leaders being developed through cognitive, behavior, and contextual approaches.

It is interesting to find that the top management commitment does not influence the agile leader and operational capabilities. In upstream oil and gas industry in Indonesia is quite complicated, uncertain, and volatile. It has required a strong leader with strong capabilities to handle the kind of situation. The leaders in the fields believe that the top management no directly helps them on the day to day operations. From this perspective, so this result is not surprising as the middle-level manager has no directly interacted with top management in headquarter. Interaction of contact between top management and the managers only by regular messages thru emails or town hall meetings quarterly. The field managers feel no direct impact on their routine activities, which is maybe exciting for future research. In this regard, the study finds that top management's corporate commitment is in the form of management support (Shah, 1996). It is achieved by allocating all of its resources (Chowdhury et al., 2007). However, not directly to develop the leadership agility.

The study also finds that operational capability is the internal factor that influences the field unit performance. According to Cepeda and Vera (2007), it is known as operational capability, as the result of dynamic capabilities and to bridge the dynamic capabilities and knowledge management fields. An operation can become superior by improving its efficiency in the operational process and reaching a competitive advantage (Day, 1994). The contemporary references stress the crucial role of the integrative method in combining various operational abilities to reach its desired goals (Dutta et al., 1999).

Teece et al. (1997) regarding dynamic capabilities, states that the increase in company performance is influenced by integrating, building, and reconfiguring company resources from external sources, positively related to positive performance improvements over time. In the oil and gas sector, all of the activities (drilling, project, and production operations) of oil and gas companies can explore exploration opportunities. They can look for new oil reserves, increase their established field oil and gas production performance, engage in operational efficiency, and have operational effectiveness (Sundewall et al., 2010). This research has some limitations. First, this study is cross-sectional research. Thus, it is suggested that future research be conducted on a longitudinal basis to get deeper insights into the oil and gas sector dynamics. Second, this research's respondents are primarily from the upstream oil and gas sector, affecting more than $80 \%$ of Indonesia's gross domestic product (GDP). 
It is suggested that future research be conducted that includes other midstream and downstream sectors that can have a more significant impact on oil and gas development. Third, the context of this empirical study is too limited to the -specific area.

It is suggested that future research be conducted to extend to other energy sectors like power and renewable energy that have a more significant impact on the country.

\section{Conclusion}

Overall, this study's output provides theoretical contributions and managerial contributions, especially for oil and gas field operations. This study demonstrates the main issues of field agile leaders' role when satisfied with IOC. In mediating by operational capability, field agile leaders lead to unit organization performance.

Since this study examined the impact factors of unit organization in the Indonesian oil and gas sector, future research must replicate the study in other industries and check the new further validate the research model. This study contributes to empirical research using the strategic agility framework of input-process-output suggested by Hitt et al. (2011) from the strategic management perspectives. The current leadership agility framework is a comprehensive framework to answer the challenges of robustness, broader scope, multilevel, and more dynamic models. Besides, detailed operational capabilities concepts as developed will enrich the agility in various contexts, which is applied in strategic management. Also, this study is one of the strategic management studies that examine strategic management.

The study provides suggestions for the corporates:

1. The corporation should strengthen the leaders' agility development as frontliner in managing the complexity and uncertainty of the oil and gas sector.

2. Top management will encourage the middle-level manager to improve operational capabilities through business process governance, team capability, planning, controlling, and evaluation.

3. To keep developing an agile leader to ensure a leader in the field has specific characteristics in managing oil and gas challenges.

\section{References:}

Acha, V., Finch, J. 2005. Paths to deepwater in the international upstream petroleum industry. Technology, Knowledge, and the Firm. Implications for Strategy and Industrial Change, 73.

Adner, R., Helfat, C.E. 2003. Corporate effects and dynamic managerial capabilities. Strategic management journal, 24(10), 1011-1025.

Aragón-Correa, J.A., Matıas-Reche, F., Senise-Barrio, M.E. 2004. Managerial discretion and corporate commitment to the natural environment. Journal of Business research, 57(9), 964-975. 
Asrilhant, B., Meadows, M., Dyson, R. 2006. Techniques to support successful strategic project management in the UK upstream oil and gas sector. European Management Journal, 24(2-3), 214-225.

Bayerl, P.S., Lauche, K. 2010. Technology effects in distributed team coordination-highinterdependency tasks in offshore oil production. Computer Supported Cooperative Work (CSCW), 19(2), 139-173.

Bentler, P.M., Chou, C.P. 1987. Practical issues in structural modeling. Sociological methods \& research, 16(1), 78-117.

Berman, S.L., Wicks, A.C., Kotha, S., Jones, T.M. 1999. Does stakeholder orientation matter? The relationship between stakeholder management models and firm financial performance. Academy of Management journal, 42(5), 488-506.

Breu, K., Hemingway, C.J., Strathern, M., Bridger, D. 2002. Workforce agility: the new employee strategy for the knowledge economy. Journal of Information Technology, 17(1), 21-31.

Cepeda, G., Vera, D. 2007. Dynamic capabilities and operational capabilities: A knowledge management perspective. Journal of business research, 60(5), 426-437.

Chang, S., Gong, Y., Shum, C. 2011. Promoting innovation in hospitality companies through human resource management practices. International Journal of Hospitality Management, 30(4), 812-818.

Chatman, J., O’Reilly, C., Chang, V. 2005. Cisco Systems: Developing a human capital strategy. California Management Review, 47(2), 137-167.

Chowdhury, M., Paul, H., Das, A. 2007. The impact of top management commitment on total quality management practice: an exploratory study in the Thai garment industry. Global Journal of Flexible Systems Management, 8(1-2), 17-29.

Christopher, M., Towill, D. 2001. An integrated model for the design of agile supply chains. International Journal of Physical Distribution \& Logistics Management, 31(4), 235246.

Cindy, M.A. 2020. How Hard COVID-19 Outbreak Could Hit Indonesia's Energy Sector? The Purnomo Yusgiantoro Center.

Collins, A.G. 1971. Oil and Gas Wells: Potential Polluters of the Environment? Journal (Water Pollution Control Federation), 2383-2393.

Cowling, K., Sugden, R. 1998. The essence of the modern corporation: markets, strategic decision-making and the theory of the firm. The Manchester School, 66(1), 59-86.

Day, G.S. 1994. The capabilities of market-driven organizations. The Journal of Marketing, 37-52.

Dutta, S., Narasimhan, O., Rajiv, S. 1999. Success in high-technology markets: Is marketing capability critical? Marketing Science, 18(4), 547-568.

Dutton, J.E., Ashford, S.J., O’Neill, R.M., Lawrence, K.A. 2001. Moves that matter: Issue selling and organizational change. Academy of Management journal, 44(4), 716736.

Eweje, G. 2006. Environmental costs and responsibilities resulting from oil exploitation in developing countries: The case of the Niger Delta of Nigeria. Journal of Business Ethics, 69(1), 27-56.

Fattouh, B., Darbouche, H. 2010. North African oil and foreign investment in changing market conditions. Energy Policy, 38(2), 1119-1129.

Floyd, S.W., Wooldridge, B. 1992. Managing strategic consensus: the foundation of effective implementation. Academy of Management Perspectives, 6(4), 27-39.

Hair, J.F., Anderson, R.E., Babin, B.J., Black, W.C. 2010. Multivariate data analysis: A global perspective. Prentice Hall, vol, 5 issue 3, 207-219. 
Hair, J.F., Hair, C.M., Sarstedt, M. 2013. Partial least squares structural equation modeling: Rigorous applications, better results and higher acceptance. Long range planning, 46(1-2), 1-12.

Haque, S.M., Green, R., Keogh, W. 2004. Collaborative relationships in the UK upstream oil and gas industry: critical success and failure factors. Problems and Perspectives in Management, 1(1), 44-50.

Hayes, R.H., Wheelwright, S.C., Clark, K.B. 1988. Dynamic manufacturing: Creating the learning organization. Simon and Schuster.

Hitt, M.A., Ireland, R.D., Sirmon, D.G., Trahms, C.A. 2011. Strategic entrepreneurship: creating value for individuals, organizations, and society. Academy of management perspectives, 25(2), 57-75.

Hopkins, W.E., Hopkins, S.A. 1997. Strategic planning-financial performance relationships in banks: a causal examination. Strategic management journal, 18(8), 635-652.

Hunt, S.D., Wood, V.R., Chonko, L.B. 1989. Corporate ethical values and organizational commitment in marketing. The Journal of Marketing, 79-90.

Joiner, B. 2009. Creating a culture of agile leaders: A developmental approach. People and Strategy, 32(4), 28.

Jöreskog, K.G., Sörbom, D. 2006. LISREL 8.80. Chicago: Scientific Software International.

Jugdev, K., Mathur, G., Fung, T.S. 2007. Project management assets and their relationship with the project management capability of the firm. International Journal of Project Management, 25(6), 560-568.

Keegan, A., Turner, J.R. 2002. The management of innovation in project-based firms. Long range planning, 35(4), 367-388.

Lengnick-Hall, C.A., Beck, T.E., Lengnick-Hall, M.L. 2011. Developing a capacity for organizational resilience through strategic human resource management. Human resource management review, 21(3), 243-255.

Lieberman, M.B., Dhawan, R. 2005. Assessing the resource base of Japanese and US auto producers: A stochastic frontier production function approach. Management Science, 51(7), 1060-1075.

Long, C. 2000. Measuring your strategic agility. Consulting to Management, 11(3), 25.

Miller, N., Pazgal, A. 2002. Relative performance as a strategic commitment mechanism. Managerial and Decision Economics, 23(2), 51-68.

Mowday, R.T., Steers, R.M., Porter, L.W. 1979. The measurement of organizational commitment. Journal of vocational behavior, 14(2), 224-247.

Narasimhan, O., Rajiv, S., Dutta, S. 2006. Absorptive capacity in high-technology markets: The competitive advantage of the haves. Marketing Science, 25(5), 510-524.

$\mathrm{Ng}$, E.S., Wyrick, C.R. 2011. Motivational bases for managing diversity: A model of leadership commitment. Human Resource Management Review, 21(4), 368-376.

O'Brien, D. 2012. Developing strategy from the middle: subsidiary strategy and the role of the subsidiary general manager. Strategic Management Society Conference (SMS), Prague.

O'Dea, A., Flin, R. 2001. Site managers and safety leadership in the offshore oil and gas industry. Safety Science, 37(1), 39-57.

Overby, E., Bharadwaj, A., Sambamurthy, V. 2006. Enterprise agility and the enabling role of information technology. European Journal of Information Systems, 15(2), 120 131.

Phene, A., Almeida, P. 2008. Innovation in multinational subsidiaries: The role of knowledge assimilation and subsidiary capabilities. Journal of international business studies, 39(5), 901-919. 
Pociovalisteanu, M.D., Thalassinos, I.E., Tirca, A. and Filho, L.W. 2010. Trends and challenges in the energy sector of Romania in the post-accession to the European Union. International Journal of Environmental Technology and Management, 12(1), 3-15, DOI: 10.1504/IJETM.2010.029957.

Porter, L.W., Steers, R.M., Mowday, R.T., Boulian, P.V. 1974. Organizational commitment, job satisfaction, and turnover among psychiatric technicians. Journal of applied psychology, 59(5), 603.

Powell, T.C. 1992. Strategic planning as competitive advantage. Strategic Management Journal, 551-558.

Prabhu, V.B., Robson, A. 2000. Impact of leadership and senior management commitment on business excellence: an empirical study in the North East of England. Total Quality Management, 11(4-6), 399-409.

Prince, J., Kay, J.M. 2003. Combining lean and agile characteristics: creation of virtual groups by enhanced production flow analysis. International Journal of production economics, 85(3), 305-318.

Ramos, S.B., Taamouti, A., Veiga, H., Wang, C.W. 2017. Do investors price industry risk? Evidence from the cross-section of the oil industry. Journal of Energy Markets, Forthcoming.

Robson, L.S., Clarke, J.A., Cullen, K., Bielecky, A., Severin, C., Bigelow, P.L., ..., Mahood, Q. 2007. The effectiveness of occupational health and safety management system interventions: a systematic review. Safety science, 45(3), 329-353.

Sakthivel, P.B. 2007. Top management commitment and overall engineering education excellence. The TQM Magazine, 19(3), 259-273.

Sambamurthy, V., Bharadwaj, A., Grover, V. 2003. Shaping agility through digital options: Reconceptualizing the role of information technology in contemporary firms. MIS quarterly, 237-263.

Shah, A.M. 1996. Strategy implementation: A study of critical factors. Indian journal of industrial relations, 42-55.

Sharifi, H., Zhang, Z. 2001. Agile manufacturing in practice-Application of a methodology. International Journal of Operations \& Production Management, 21(5/6), 772-794. DOI: 10.1108/01443570110390462.

Sheikhzadeh, M., Arasti, M.R., Kotobzadeh, R. 2012. Identifying key success factors in upstream sector of oil and gas industry in Iran. African Journal of Business Management, 6(20), 6156-6165.

Sirmon, D.G., Hitt, M.A. 2009. Contingencies within dynamic managerial capabilities: Interdependent effects of resource investment and deployment on firm performance. Strategic Management Journal, 30(13), 1375-1394.

Staw, B.M. 1976. Knee-deep in the big muddy: A study of escalating commitment to a chosen course of action. Organizational behavior and human performance, 16(1), $27-44$.

Stekelenburg, J.V. 2012. Exploring organizational agility and the added value of human resources: Creating organizational agility by using individual competencies and organizational practices. Unpublished Master's Thesis, Tilburg University, Tilburg, Netherlands.

Stonham, P. 2000. BP Amoco: integrating competitive and financial strategy. Part one: strategic planning in the oil industry. European Management Journal, 18(4), 411419.

Sundewall, J., Jönsson, K., Cheelo, C., Tomson, G. 2010. Stakeholder perceptions of aid coordination implementation in the Zambian health sector. Health Policy, 95(2-3), $122-128$. 
Teece, D.J., Pisano, G., Shuen, A. 1997. Dynamic capabilities and strategic management. Strategic management journal, 18(7), 509-533.

Teece, D., Peteraf, M., Leih, S. 2016. Dynamic capabilities and organizational agility: Risk, uncertainty, and strategy in the innovation economy. California Management Review, 58(4), 13-35.

Thao, T.P. 2012. Enterprise systems and organisational agility: Developing and exploring a Causal Model. Doctor of Philosophy, School of Business Information Technology and Logistics Business College, RMIT University.

Van Der Vegt, G.S., Essens, P., Wahlström, M., George, G. 2015. Managing risk and resilience. Academy of Management. https://doi.org/10.5465/amj.2015.4004.

Van der Vegt, G.S., Janssen, O. 2003. Joint impact of interdependence and group diversity on innovation. Journal of management, 29(5), 729-751.

Vecchio, R.P., Gobdel, B.C. 1984. The vertical dyad linkage model of leadership: Problems and prospects. Organizational behavior and human performance, 34(1), 5-20.

Wijanto, S.H. 2015. Metode penelitian menggunakan structural equation modeling dengan lisrel 9. Jakarta: Lembaga Penerbit Fakultas Ekonomi UI.

Zahra, S.A., George, G. 2002. Absorptive capacity: A review, reconceptualization, and extension. Academy of management review, 27(2), 185-203.

Zhang, Z., Sharifi, H. 2000. A methodology for achieving agility in manufacturing organisations. International Journal of Operations \& Production Management, 20(4), 496-513.

Zhao, H., Hsu, C.C. 2007. Social ties and foreign market entry: An empirical inquiry. Management International Review, 47(6), 815-844.

Zott, C. 2003. Dynamic capabilities and the emergence of intraindustry differential firm performance: insights from a simulation study. Strategic management journal, 24(2), 97-125. 